\title{
The Physical and Cultural Attributes of Ethnic Enclave: A Basis for Conservation
}

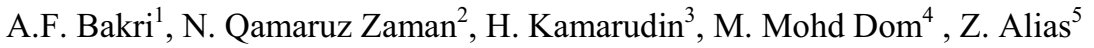 \\ 1,2,3,4,5 Faculty of Architecture, Planning \& Surveying, Universiti Teknologi MARA, 40450 Shah \\ Alam, Selangor, Malaysia
}

\begin{abstract}
Ethnic enclaves exist in many countries as a manifestation of the immigrants' identity and the connection to their homeland. This research investigates on the tangible and intangible attributes of an ethnic enclave. The study was conducted on Little India, Penang and 'Little India' of Klang through observations and interviews, with literature review, to form the research framework. The data obtained were matched against Part X Clause 67 (1) and (2) of the National Heritage Act 2005. Though not listed as National Heritage, it was found that both sites possess significant physical and cultural attributes which could be used as a basis for conservation framework of ethnic enclave while maintaining its authenticity.
\end{abstract}

\section{Introduction}

Ethnic enclaves exist all around the world as a manifestation of what the immigrants had at home and how they blend with the mainstream economy. Although on the surface, they portray strong identity of the people that they represent, however it is still questionable, whether the enclave is conserved, both culturally, and physically. People in the ethnic enclave represent and practice the culture and custom which are not only confined within the built environment, but also on the street. A combination of these practices provides a sense of familiarity, engagement as well as a sense of place. Without the culture and customs, the built environment would remain soulless, thus betraying the idea of an ethnic enclave in principles. Studies have shown that built environment, social activities and public ritual events are three aspects that can create a sense of place and are essential for the immigrants as they settle themselves in foreign lands.

\section{Literature Review}

\subsection{Concept of Ethnic Enclave}

Ethnic enclave is widely denoted in the literature as spaces of cultural identity, community of choices, and ethnic economy Ghosh [1]. Yuryevich [2] defines ethnic enclaves as a place of people with same ethnicity or religion. The characteristics were further described by Digby [3] as well as Wilson and Portes [4] as a group of people who do not speak the mother tongue of the host country, celebrate different festivals, different beliefs, eat different foods and dress differently, compared to the majority of the population. Abrahamson as cited by Mazumdar et al [5] defines urban enclaves as 
'concentration of residents which share a distinctive status that is important to their identity; specialized stores and institutions that provide local support for the residents' distinctive lifestyle and the geographic space the resident occupy.'

Meanwhile, Portes and Bach [6] coined the term ethnic enclave based on the two most crucial features - the presence of immigrants with social capital and wide division of labour. The first wave of immigrants is the businessman or traders who have the capital, than the second waves of the immigrants, which are dominated by the less wealthy ones came to work for the traders. The former will provide the latter with job opportunities, comfort and a greater chance to utilize their skills and knowledge. This is also supported by Hedberg and Tammaru [7] who suggested that educated immigrants will get a better chance in obtaining a job in the host country as compared to the uneducated one.

Therefore, social contact is very important in ensuring the productivity and success of people in ethnic enclaves. Little India, Little Tokyo, Chinatown, and Little Saigon are some examples of ethnic enclave, which has become part of the urban landscape. The existence is largely due to several factors that triggered the migration process such as poverty, economic crisis, political instability, and working opportunity. These people migrated for various reasons, and ethnic enclaves are looked upon as a support system in their newfound home [5].

\subsection{The need to sustain the cultural attributes of ethnic enclaves}

The Australia ICOMOS Burra Charter [8] describes 'cultural significance' as the aesthetic, historic, scientific, social or spiritual value for past, present or future generations. As stated in the same article, 'cultural significance is embodied in the place itself, its fabric, setting, use, associations, meanings, records, related places and related objects'. The term is associated with heritage significance and cultural heritage value, more often than not. The charter also stated that cultural significance may vary with the layer of history of the area where it belongs. As such, cultural practice is understood as a result of long-term practice, accepted, and modified to suit the prevailing circumstances.

\subsection{Cultural attributes of an ethnic enclave}

Based on literature reviews, the cultural attributes of an ethnic enclave can be summarized as follows:

- People / social group

The initial dwellers are immigrants and can be of multi-ethnicity. They came from the same country, share the same religion and culture, and are dominant in that area. They may be of various age groups and may consist of sub-cultural groups.

- Language

They speak their mother tongue though with varied dialects. Immigrants also tend to learn the local language.

- Celebrations

Festivals, celebrations, and ceremonies make the ethnic enclave livelier and create opportunities for gatherings and strengthening the ties between them.

- Religion

As religion could also be interpreted as a way of life, immigrants bring their faith as continuity of their lives back home. It also acts as a binding force for them, being away from family and relatives. 
- Attire

Attire is one way of recognizing their hometown.

- Ritual and practice

They perform the same rituals and practices as those back home.

- Food

Food and cuisines represent culture, religion and group attachment amongst the people.

- Business

It emerged due to discrimination and social segregation, and the major business is usually food. They are highly dependent on co-ethnic network due to trust, comfort and familiarity.

\subsection{The need to sustain the physical attributes of ethnic enclaves}

The physical attributes accommodate for human interaction and activities. It also plays a significant role in maintaining the associations of their place of origin. Everywhere, these ethnic groups tried their very best to imitate the architecture of their hometown to the enclave as it could evoke memories of their place of origin. Chako and Cheung [9] clarified that Ethiopians in Los Angeles mark their enclave territory by projecting their identity.

Their pride was manifested in the features and colour scheme used in the exterior and interior as well as the language used for the signages. Chako and Cheung [9] also highlighted "sometimes the 'gojo', a type of Ethiopians thatched roof is incorporated into the décor or patrons are seated around 'messobs', traditional dining tables made of goat skin stretched over drums.'

In support for this, Mazumdar et al [5] mentioned that in Little Saigon of Westminster, California; Vietnamese architectural features were used to highlight the image of the area and to create the sense of place. Familiar architectural forms such as gateway, arches and curved roofs help the Vietnamese to retain the memory of their birthplace and ancestors.

\subsection{Physical attributes of an ethnic enclave}

Based on literature reviews, the physical attributes of an ethnic enclave can be summarized as follows:

\section{- Location}

The location is in the urban area or downtown. In most cases, ethnic enclaves are located in the older part of the city.

- Settlement pattern

The settlement pattern may have evolved through the years and have the potential to continue evolving in the future. The morphology of the settlement pattern is important for conservation as it may change due to the requirements set by the host country. It could also provide information on how immigrants adapt to changes while maintaining their identity.

- Public realms

Decoration, streetscape and public realms could enhance the identity of the area.

- Architecture

The architectural style, interior design and colour scheme reflect those at home while the signages are in the characters of their language. 


\section{Study Methods}

Qualitative method is used in the data collection. There are two types of data needed: the primary and the secondary data. The first part of the case study involved extensive observation of the site. Data obtained include the types of business activities, their ways of life, religion, language, sub-cultural group and festivals that form the richness of the area.

The second instrument was an interview, where people responding orally to structured questions or expressing their views about the place. The respondents include the employee of the local authorities (Klang Municipal Council and Pulau Pinang Municipal Council), the building owners, the locals and tourists. Secondary data were obtained from books, journals, theses, articles, websites, newspaper and other relevant publications available from UiTM Library, the National Archive and the Heritage Trust of Malaysia. The data obtained were analysed against Part X Clause 67 (1) and (2) of the National Heritage Act 2005 in understanding the significance of Indian ethnic enclaves as a basis for the conservation approach.

\section{4 'Little India' of Klang and Little India, Penang - An Overview}

The study was carried out at 'Little India' of Klang and Little India of Penang. Both areas were chosen due to the rich Indian culture that they contain and the fact that they still survive until today. Very little is known on the history of the formation of 'Little India' in Klang except the word of mouth. From an interview with one of the traders there, it is believed that the Indians have started to settle there from the late $19^{\text {th }}$ century.

Based on historical findings, Indians were brought in to Selangor by the British to work in plantations as well as road and railway construction yards. Amongst the first arrivals were by the Indian Muslims merchants from Gujarat. Initially, Jalan Tengku Kelana was known as Rembau Street. The name was then changed to Jalan Tengku Kelana when Klang was declared as The Royal Town. The term 'Little India' was coined by the locals and tourists. It was never acknowledged and declared by the local authority as they usually address the area as 'business area at Jalan Tengku Kelana'. For the purpose of this study, the researchers have defined the area to include Jalan Tengku Kelana, Jalan Pulasan, Jalan Yeo Guan Hup, Jalan Dato' Hamzah and Lorong Tingkat.

Little India of Penang on the other hand has a very long history and has become a tourist attraction. According to Bhatt [10], settlement at Little India started in the early $19^{\text {th }}$ century when traders and labourers from southern India came to start a new life there. They settled in Chulia Street, one of the first streets planned under the administration of Captain Francis Light. Initially, business was carried out to cater for their own needs. Utaka [11] explained that some of the shophouses at Little India were destroyed by the Japanese during World War II. However, the buildings were later rebuilt. The name Little India was introduced by the local authorities in the early 1990s. Until today, this area still becomes a favourite tourist spot to experience the rich and unique culture of the Indians which has started since the British occupation in the Straits Settlement including Penang.

\section{Findings}

The following subheadings will discuss on the attributes of Little India. By categorizing and understanding the attributes, identification can be made on the significance of these ethnic enclaves as spelled out by National Heritage Act 2005 or Act 645 [12], which will form a sound basis for the conservation. 


\subsection{Physical attributes of Little India}

Table 1: Summary of physical attributes at 'Little India' Klang and Little India Penang

\begin{tabular}{|c|c|c|}
\hline Attribute & 'Little India', Klang & Little India, Penang \\
\hline Location & $\begin{array}{l}\text { - Located in the old administration and } \\
\text { commercial area of Klang. } \\
\text {-Within proximity to Klang river, KTMB } \\
\text { railway station and religious institutions. } \\
\text { - Become one of the most popular shopping } \\
\text { destinations for Indians product in Malaysia. }\end{array}$ & $\begin{array}{l}\text { - Located at the Historic Commercial District } \\
\text { of Georgetown. } \\
\text { - Within proximity to the jetty and other } \\
\text { ethnic nclaves. }\end{array}$ \\
\hline $\begin{array}{l}\text { Settlemen } \\
\text { t pattern }\end{array}$ & $\begin{array}{l}\text { - Evolved from a business area to an ethnic } \\
\text { enclave. Chinese once dominated the area } \\
\text { but later was then taken again by the } \\
\text { Indians. }\end{array}$ & $\begin{array}{l}\text { - It was the settlement of Indian traders and } \\
\text { the area was planned by Sir Francis Light. } \\
\text { - In early days, the area was full of bungalow } \\
\text { lots, but it was subdivided into smaller ones } \\
\text { to build shophouses. }\end{array}$ \\
\hline $\begin{array}{l}\text { Public } \\
\text { realms }\end{array}$ & $\begin{array}{l}\text { - Public realms are of typical local authority } \\
\text { design and in a poor condition. } \\
\text { - Lack of soft landscape. } \\
\text { - Unsatisfactory pedestrian walkway. } \\
\text {-Insufficient parking area causing illegal and } \\
\text { unorganized parking especially during } \\
\text { weekends. }\end{array}$ & $\begin{array}{l}\text { - Road decoration and streetscape are of } \\
\text { Indian identity with the use of icons and } \\
\text { symbols. } \\
\text { - Others public realms are of typical local } \\
\text { authority design and some are in bad } \\
\text { condition. } \\
\text { - Insufficient green area with some attempts } \\
\text { to introduce landscape to soften the area. }\end{array}$ \\
\hline $\begin{array}{l}\text { Architect } \\
\text { ure/ } \\
\text { Building } \\
\text { typology }\end{array}$ & $\begin{array}{l}\text { - Shophouses of varieties of architectural } \\
\text { features is the main building typology and } \\
\text { was introduced by the British. } \\
\text { - Other typologies include religious } \\
\text { institutions such as mosque, Hindu temple } \\
\text { and church. }\end{array}$ & $\begin{array}{l}\text { - Shophouses of varieties of architectural } \\
\text { features is the main building typology and } \\
\text { was introduced by the British. } \\
\text { - Other typologies include religious } \\
\text { institutions such as mosque, Hindu temple } \\
\text { and Buddhist temple. }\end{array}$ \\
\hline $\begin{array}{l}\text { Building } \\
\text { styles }\end{array}$ & $\begin{array}{l}\text {-Influenced by migrants e.g. mosque and } \\
\text { Indian temple from South India. }\end{array}$ & $\begin{array}{l}\text { - Influenced by migrants: mosque and Indian } \\
\text { temple from South India, shophouses from } \\
\text { China. }\end{array}$ \\
\hline Colour & $\begin{array}{l}\text {-Use of bright and variety of colours } \\
\text { especially at building facades and signages. } \\
\text { - No control and specific regulations. } \\
\end{array}$ & $\begin{array}{l}\text { - Use of bright and variety of colours } \\
\text { especially at building facades and signages. } \\
\text { - Controlled by specific regulations. }\end{array}$ \\
\hline Signage & $\begin{array}{l}\text {-Use of Tamil characters and English } \\
\text { language. } \\
\text { - No specific regulation on the size of } \\
\text { signages. }\end{array}$ & $\begin{array}{l}\text { - Use of Tamil characters, Malay and English } \\
\text { language. } \\
\text { - Controlled by specific regulations in terms } \\
\text { of size and placement of signages. }\end{array}$ \\
\hline $\begin{array}{l}\text { Architect } \\
\text { ural } \\
\text { feature }\end{array}$ & $\begin{array}{l}\text { - Certain buildings such as temple display } \\
\text { features of Indian architecture, others may } \\
\text { depend on the ethnic influence. } \\
\text { - Use of figurines and intricate details at } \\
\text { temple. }\end{array}$ & $\begin{array}{l}\text { - Certain buildings such as temples display } \\
\text { features of Indian architecture,others may } \\
\text { depend on the ethnic influence. } \\
\text { - Use of figurines and intricate details at } \\
\text { temple. }\end{array}$ \\
\hline $\begin{array}{c}\text { Interior } \\
\text { design }\end{array}$ & $\begin{array}{l}\text {-Depends on the types of business they } \\
\text { operate. } \\
\text { - Mostly, traders have shown some } \\
\text { indications to the client on their religion - } \\
\text { shrine, Quran verses. }\end{array}$ & $\begin{array}{l}\text { - Depends on the types of business they } \\
\text { operate. } \\
\text { - Mostly, traders have shown some } \\
\text { indications to the client on their religion- } \\
\text { shrine, Quran verses. }\end{array}$ \\
\hline
\end{tabular}




\subsection{Cultural attributes of Little India}

Table 2: Summary of cultural attributes at 'Little India' Klang and Little India Penang

\begin{tabular}{|c|c|c|}
\hline Attribute & 'Little India', Klang & Little India, Penang \\
\hline $\begin{array}{l}\text { People/ } \\
\text { social } \\
\text { groups }\end{array}$ & $\begin{array}{l}\text { - Indians are the dominant ethnic group. } \\
\text { - There are Indians of different sub cultures - } \\
\text { Tamil, Gujaratis, etc. } \\
\text { - Their ties become strong with the help of } \\
\text { associations such as Indian Chamber and } \\
\text { mosque committee. }\end{array}$ & $\begin{array}{l}\text { - Indians are the dominant ethnic group. } \\
\text { - There are Indians of different sub cultures- } \\
\text { Tamil, Gujaratis, Punjabis, Telegus, } \\
\text { Malayalees, Sindhi, etc. } \\
\text { - Their ties become strong with the help of } \\
\text { associations such as Indian Chamber, Penang } \\
\text { Muslim League, Chinese associations. }\end{array}$ \\
\hline Language & $\begin{array}{l}\text { - Mainly Tamil, Malay and English. } \\
\text { - Varies according to their sub- cultural } \\
\text { group. } \\
\text { - Some has adapted English fluently, some } \\
\text { can speak both Malay and English. }\end{array}$ & $\begin{array}{l}\text { - Mainly Tamil, Malay and English. } \\
\text { - Varies according to their sub- cultural group. } \\
\text { - Some has adapted English fluently, some can } \\
\text { speak both Malay and English. }\end{array}$ \\
\hline $\begin{array}{l}\text { Festivals, } \\
\text { celebration } \\
\text { s and } \\
\text { ceremonie } \\
\quad \mathrm{s} \\
\end{array}$ & $\begin{array}{l}\text { - Full of colours and involves many rituals. } \\
\text { - Involves all age group who enjoy it in } \\
\text { several different ways. } \\
\text { - Concentrate more on Indian festivals and } \\
\text { celebrations. }\end{array}$ & $\begin{array}{l}\text { - Full of colours and involves many rituals. } \\
\text { - Involves all age group who enjoy it in several } \\
\text { different ways. } \\
\text { - Celebrates both Malay and Indian festivals } \\
\text { and celebrations. } \\
\end{array}$ \\
\hline Religion & $\begin{array}{l}\text { - Mainly Hindu, Muslim. } \\
\text { - Religious institution as a place of worship } \\
\text { and gathering. } \\
\text { - Important as spiritual support for the } \\
\text { people. }\end{array}$ & $\begin{array}{l}\text { - Mainly Hindu, Muslim and Buddhist. } \\
\text { - Religious institution as a place of worship } \\
\text { and gathering. } \\
\text { - Important as spiritual support for the people. }\end{array}$ \\
\hline Attire & $\begin{array}{l}\text { - Traditional attire is used during festivals } \\
\text { and celebrations. }\end{array}$ & $\begin{array}{l}\text { - Traditional attire is used extensively during } \\
\text { festivals and celebrations }\end{array}$ \\
\hline $\begin{array}{l}\text { Rituals } \\
\text { and } \\
\text { practice }\end{array}$ & $\begin{array}{l}\text { - Some ritual events are individual, and some } \\
\text { are at large scale. } \\
\text { - Still follow traditional rituals and practices. }\end{array}$ & $\begin{array}{l}\text { - Some ritual events are individual, and some } \\
\text { are at large scale. } \\
\text { - Still follow traditional rituals and practices. }\end{array}$ \\
\hline Food & $\begin{array}{l}\text { Extensive use of herbs and spices. } \\
\text { Majority still uses traditional recipe for } \\
\text { cooking. }\end{array}$ & $\begin{array}{l}\text { - Extensive use of herbs and spices. } \\
\text { - Majority still uses traditional recipe for } \\
\text { cooking. }\end{array}$ \\
\hline Business & $\begin{array}{l}\text { - Most shops cater to Indian needs. } \\
\text { - A lot of the current trade in the area is not } \\
\text { very much of the authentic and original } \\
\text { ones. }\end{array}$ & $\begin{array}{l}\text { - Most shops cater to Indian needs. } \\
\text { - Some traditional trades still exist, where } \\
\text { some are endangered such as the songkok } \\
\text { maker, traditional jewelleries maker, } \\
\text { traditional signboard, 'ottu kedai'. }\end{array}$ \\
\hline
\end{tabular}

\section{Discussion}

Ethnic enclave is part of our heritage assets. According to Rahman [13], heritage assets are unique, valuable, and should be well conserved and managed. The National Heritage Act 2005 or Act 645 [12] is a legal tool that governs the management of heritage in the country and conservation is just another aspect of heritage management spelled out in the act. In the case of the Little India of Penang and 'Little India' of Klang, both are not listed as National Heritage, however, understanding the criteria for the nomination of National Heritage is a way of how we can define the significance of both ethnic enclaves. In Part X of the act, the criteria outlined in the nomination of a National Heritage are as follows:

(a) The historical importance, association with or relationship to Malaysian history

(b) The good design or aesthetic characteristics

(c) The scientific or technical innovations or achievements 
(d) The social or cultural association

(e) The potential to educate, illustrate or provide further scientific investigation in relation to Malaysian cultural heritage

(f) The importance in exhibiting a richness, diversity or unusual integration of features

(g) The rarity or uniqueness of the natural heritage, tangible or intangible cultural heritage or underwater cultural heritage

(h) The representative nature of a site or object as part of a class or type of a site or object; and

(i) Any other matter which is relevant to the determination of cultural heritage significance

From the data obtained, we can see that both Little India, Penang and 'Little India' of Klang have the significance comparable to subsection (a), (d) and (f) of Part X Clause 67 (1) and (2) of the National Heritage Act 2005 [12]. In terms of their historical significance, the two enclaves are located in the old quarter of early administrative centers in Federated Malay States and the Straits Settlements, both significant as part of British Colonization history of the country.

\section{Conclusion}

Both ethnic enclaves express strong social and cultural associations amongst the people. In terms of exhibiting richness, diversity or unusual integration of features, this can be seen both in their architecture, where the blending of authentic India features with local architectural solutions occur; and in the culture, where there is a strong assimilation of what was brought from mainland India with the local culture. Having understood this, preparation of a holistic conservation plan will be more objective and purposeful.

\section{Acknowledgement}

This study is funded by Research Intensive Faculty (RIF), project no: 600-RMI/DANA 5/3/RIF (775/2012) provided by Research Management Institute of Universiti Teknologi MARA Shah Alam, Malaysia.

\section{References}

1. Ghosh, S., 2007. Transnational Ties and Intra-Immigrant Group Settlement Experience: A Case Study of Indian Bengalis and Bangladeshis in Toronto. Geo-Journal.

2. Yuryevich, E., 2005. Theory of Enclaves. Retrieved on June 21, 2008

3. Digby, B., 2006. Ethnic Enclaves in Large Cities. Geo Date Volume 19, Number 3. Retrieved May 4, 2008 from EBSCOHost database

4. Wilson,K. \& Portes,A., 1980. Immigrant enclaves: An analysis of the labor market experiences of Cubans in Miami. American Journal of Sociology, 86: 295-319.

5. Mazumdar S., Mazumdar S., Docunayan F., \& McLaughlin C. M., 2000. Creating a Sense of Place: The Vietnamese-Americans and Little Saigon. Journal of Environmental Psychology.

6. Portes, A., \& Bach, R. L., 1985. Latin Journey: Cuban and Mexican Immigrants in the United States. Berkeley, CA: University of California Press.

7. Hedberg, C \& Tammaru, T., 2012. 'Neighbourhood Effects' and 'City Effects': The Entry of Newly Arrived Immigrants into the Labour Market. Urban Studies

8. Australia ICOMOS., 1999. The Burra Charter -The Australian ICOMOS Charter for Places of Cultural Significance. Australia: Australia ICOMOS Incorporated. 
9. Chako,E \& Cheung, I., 2006. The Formation of a Contemporary Ethnic Enclave: The Case of "Little Ethiopia" in Los Angeles. In Frazier, J.W. \& Tettey-fio, E, Race, Ethnicity, and Place in a Changing America. United States of America: Global Academic Publishing.

10. Bhatt, H., 2002. The Little India of George Town. Paper presented at the Penang Story International Conference 2002, Penang.

11. Utaka, Y., 2002. Conserving the Living Culture: Lessons from Little India. Paper presented at the International Symposium- Penang Story.

12. Government of Malaysia. 2005. National Heritage Act 2005 (Act 645). Kuala Lumpur: International Law Books Services.

13. Rahman, S., 2013. Heritage Management Challenges in Historic Town of Ludlow, England. World Applied Sciences Journal 24 (12): 1589-1596 